\title{
WORKSHOP ISU-ISU STRATEGIS DALAM ALABAR UNTUK MAHASISWA PEMINAT ALJABAR DI UNIVERSITAS MATARAM
}

\author{
Ni Wayan Switrayni ${ }^{*}$, Mamika Ujianita Romdhini, I Gede Adhitya Wisnu W., \\ Irwansyah \\ Program Studi Matematika, FMIPA Universitas Mataram \\ Jalan Majapahit Nomor 62, Mataram 83125 \\ *alamat korespondensi: niwayan.switrayni@unram.ac.id
}

\begin{abstract}
ABSTRAK
Matematika merupakan salah satu ilmu yang sangat penting dalam perkembangan peradaban kehidupan manusia. Aljabar adalah salah satu bidang dalam matematika yang merupakan tonggak utama dalam perkembangan bidangbidang lainnya, akan tetapi jumlah mahasiswa peminat aljabar khususnya di Universitas Mataram sangatlah sedikit begitu pula dengan hasil-hasil tulisan ilmiah pada bidang ini. Oleh karena itu, kegiatan ini bertujuan untuk meningkatkan motivasi, minat dan pengetahuan mahasiswa khususnya peminat aljabar di Universitas Mataram dalam bidang aljabar dan aplikasinya. Metode pendekatan yang akan diterapkan adalah melalui workshop yang berisi isu-isu dalam aljabar yang sedang hangat dibicarakan dan beberapa aplikasinya. Adapun hasil dari kegiatan workshop isu-isu strategis dalam aljabar ini adalah motivasi, minat, dan pengetahuan mahasiswa peminat aljabar di Universitas Mataram meningkat dalam bidang aljabar dan aplikasinya. Dapat disimpulkan bahwa kegiatan tersebut sangat bermanfaat bagi para mahasiswa peminat aljabar di Universitas Mataram, yaitu dalam hal meningkatnya pengetahuan dan wawasan mahasiswa peminat aljabar di Universitas Mataram terhadap topik-topik aljabar yang sedang menjadi trend masa kini khususnya yang mengarah pada aplikasinya dalam dunia nyata Selain itu, mahasiswa juga lebih mudah menentukan rencana topik-topik penelitian baik untuk dijadikan bahan karya ilmiah maupun topik skripsi.
\end{abstract}

Kata kunci: workshop, aljabar, aplikasi aljabar

\section{PENDAHULUAN}

Perubahan peradaban dalam kehidupan manusia sangat ditentukan oleh kemajuan ilmu pengetahuan dan teknologi pada masa itu. Hampir semua permasalahan dan tantangan pada setiap masa dapat terjawab secara sainstifik. Matematika yang merupakan salah satu disiplin ilmu pasti sangat banyak berperan dalam 


$\begin{array}{llr}\begin{array}{l}\text { memberikan jawaban dari } \\ \text { permasalahan dan tantangan }\end{array} & \begin{array}{l}\text { merupakan topik utama dalam } \\ \text { matematika tingkat lanjut, yang }\end{array} \\ \text { tersebut khususnya aljabar. } & \text { dipelajari terutama oleh para } \\ \text { Aljabar (dari bahasa arab "al- } & \text { profesional dan pakar matematika } \\ \text { jabr" yang berarti "pengumpulan } & \text { (Wikipedia, 2018). } & \text { Dalam } \\ \text { bagian yang rusak) adalah salah satu } & \text { perkembangannya, } & \text { seorang } \\ \text { bagian dari bidang matematika yang } & \text { matematikawan, } & \text { Bourbaki } \\ \text { luas, bersama-sama dengan teori } & \text { mengidentifikasi bahwa ada tiga } \\ \text { bilangan, geometri dan analisis. } & \text { bidang utama yang menjadi tonggak } \\ \text { Dalam bentuk paling umum, aljabar } & \text { terdepan dalam perkembangan } \\ \text { adalah ilmu yang mempelajari simbol- } & \text { aljabar modern yakni teori aljabar } \\ \text { simbol matematika dan aturan untuk } & \text { bilangan, teori grup, serta aljabar } \\ \text { memanipulasi simbol-simbol ini. } & \text { linear dan sistem hypercomplex } \\ \text { Aljabar adalah benang pemersatu dari } & \text { (Lady, 2018). }\end{array}$

hampir semua bidang matematika.

Di Perguruan Tinggi,

Selain itu, aljabar juga meliputi segala khususnya di Program Studi sesuatu dari dasar pemecahan Matematika Universitas Mataram, persamaan untuk mempelajari terdapat beberapa kelompok riset abstraksi seperti grup, gelanggang, yakni kelompok riset Aljabar, Analisis, dan medan. Semakin banyak bagian- Terapan dan Statistika. Akibatnya, bagian dasar dari aljabar disebut dalam kurikulumnya pun terkandung aljabar elementer, sementara bagian mata kuliah - mata kuliah yang sesuai aljabar yang lebih abstrak yang dengan kelompok - kelompok riset disebut aljabar abstrak atau aljabar modern. Aljabar elementer umumnya dianggap penting untuk setiap studi matematika, ilmu pengetahuan, atau teknik, serta aplikasi dalam kesehatan dan ekonomi. Aljabar abstrak tersebut. Adapun minat mahasiswa juga tersebar pada kelompokkelompok matakuliah tersebut. Akan tetapi, sebaran minat para mahasiswa ini tidaklah merata. Tidak banyak mahasiswa yang memiliki bidang 
minat pada Matematika Murni khususnya aljabar. Hal ini dikarenakan oleh banyak mahasiswa yang beranggapan bahwa matakuliahmatakuliah aljabar cendrung lebih sulit dibandingkan yang lainnya. Selain itu, fakta yang ada menunjukkan bahwa pada setiap periode penyusunan skripsi hanya sedikit mahasiswa yang mengangkat topik di bidang aljabar.

Beberapa alasan yang cukup dipandang logis yang menyebabkan bahwa mahasiswa peminat aljabar di Program Studi Matematika khususnya adalah karena kurangnya wawasan dan pengetahuan tentang aljabar dan perkembangannya. Banyak anggapan bahwa dalam aljabar hanya berisi teori-teori klasik dalam Matematika. Tidak banyak yang mengetahui bahwa sudah terjadi perkembangan yang pesat dalam dunia aljabar baik dari segi teori maupun aplikasinya. Banyak mahasiswa belum mengetahui penggunaan aljabar dalam dunia nyata. Hal ini menjadi salah satu penyebab banyak mahasiswa jarang mengangkat topik aljabar sebagai skripsinya.

$$
\text { Salah satu cara untuk }
$$
mengatasi masalah di atas adalah dengan memberikan workshop yang berisi materi tentang perkembangan aljabar dan aplikasinya. Oleh karena itu, dalam Kegiatan Pengabdian Kepada Masyarakat untuk anggaran DIPA PNBP Unram Tahun 2018, kelompok riset Aljabar dari Program Studi Matematika Fakultas Matematika dan Ilmu Pengetahuan Alam Universitas Mataram akan mengadakan suatu kegiatan Workshop Isu-isu Strategis dalam Aljabar untuk Mahasiswa Peminat Aljabar di Universitas Mataram. Kegiatan ini bertujuan untuk meningkatkan motivasi, minat dan pengetahuan mahasiswa peminat aljabar di Universitas Mataram dalam bidang aljabar dan aplikasinya khususnya yang terkait dengan topiktopik aljabar yang sedang menjadi trend masa kini. 


\section{METODE KEGIATAN}

Metode pendekatan yang diterapkan adalah dengan pola pembimbingan yaitu melalui pemaparan dan diskusi kepada para mahasiswa peminat aljabar di Universitas Mataram terkait isu-isu strategis dalam aljabar dan aplikasinya. Tahap awal adalah dimulai dengan menyiapkan materi workshop yang berisi tentang topiktopik aljabar dan aplikasinya dalam kehidupan nyata. Secara umum, topik-topik yang dimaksud adalah: (1). Teori pengkodean, persandian, dan aplikasinya dalam teknologi masa kini; (2). Hyperplane Arrangement; (3). Matriks Leslie dan aplikasinya dalam kehidupan nyata; (4). Abstraksi Bilangan prima dan aplikasinya. Tahap kedua adalah memberikan sosialisasi kepada para mahasiswa peminat aljabar di Universitas Mataram terkait dengan pelaksanaan workshop tersebut. Tahap ketiga adalah pelaksanaan kegiatan Pengabdian Kepada Masyarakat. Kegiatan Pengabdian Kepada Masyarakat ini akan dilaksanakan di FMIPA
Universitas Mataram tanggal 27 Nopember 2018.

\section{HASIL DAN PEMBAHASAN}

Dalam rangka memecahkan permasalahan yang telah disebutkan sebelumnya, pada kegiatan Pengabdian Kepada Masyarakat ini telah dilakukan Workshop Isu-isu Strategis dalam Aljabar dan Aplikasinya. Kegiatan workshop tersebut dilaksanakan pada tanggal 27 Nopember 2018 dan bertempat di Fakultas Matematika dan IImu Pengetahuan Alam Universitas Mataram.

Kegiatan workshop ini dihadiri oleh mahasiswa peminat aljabar di Universitas Mataram yang berasal dari mahasiswa Fakultas Matematika dan Ilmu Pengetahuan Alam dan juga Fakultas Keguruan dan IImu Pendidikan. Kegiatan ini di awali dengan acara pembukaan oleh tim pengabdian. Pada tahap ini mahasiswa peminat aljabar di Universitas Mataram diberikan gambaran umum terkait isu-isu terikini yang sedang berkembang dan 
hangat dibicarakan di dunia aljabar terkait dengan perkembangan teori dan terapannya dalam pemecahan masalah nyata.

Tahap selanjutnya adalah penyajian materi oleh tim pengabdian di mana setiap pemateri diberikan waktu maksimum 45 menit. Materi pertama yang disampaikan adalah terkait dengan salah satu terapan aljabar yaitu dalam bidang kriptografi. Pada bagian ini mahasiswa diberikan beberapa contoh permasalahan nyata dalam dunia kriptografi seperti masalah keamanan data/pesan. Selanjutnya dalam rangka menyelesaikan permasalahanpermasalahan tersebut maka diberikanlah beberapa solusi yang terkait dengan teori koding sehingga data/pesan yang disampaikan terjaga kerahasiaannya. Tahap ini diakhiri dengan sesi tanya jawab.

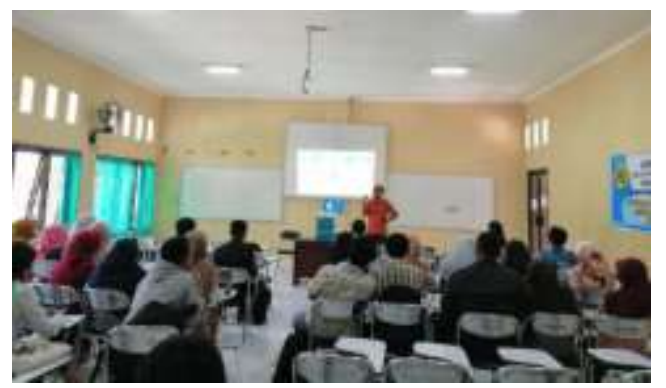

Gambar 1. Pemberian materi kepada peserta workshop
Materi berikutnya yang disampaikan adalah terkait dengan perkembangan teori aljabar geometri yaitu hyperplane arrangement. Suatu (affine) hyperplane arrangement adalah suatu koleksi hingga dari (affine) hyperplane pada suatu ruang vektor (Dimca, 2017).

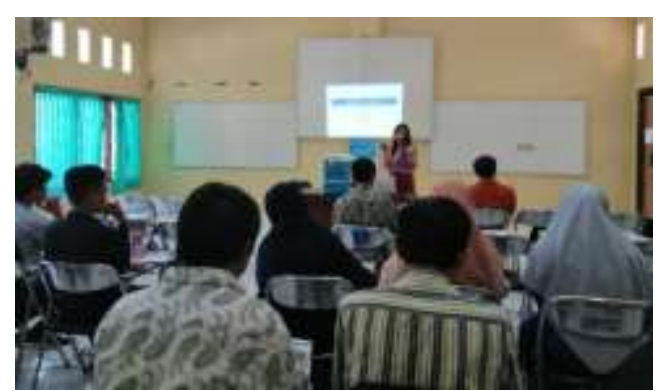

Gambar 2. Pemaparan materi tentang perkembangan teori aljabar

Pada tahap ini dipaparkan perkembangan teori aljabar khususnya aljabar geometri yang terkait dengan hyperplane arrangement dan beberapa aplikasinya dalam geometri, lapangan hingga, dan juga pewarnaan graf. Tahap ini juga diakhiri dengan sesi tanya jawab.

Materi ketiga adalah terkait dengan aplikasi aljabar yaitu tentang perkembangan Matriks Leslie dan terapannya. Salah satu model 
pertumbuhan populasi yang terkenal yang digunakan oleh para demographer adalah model Leslie yang berkembang pada Tahun 1940an dan menggunakan aplikasi matriks yang selanjutnya dikenal dengan matriks Leslie (Anton, 2014). Pada bagian ini dipaparkan hasil-hasil riset terkait penggunaan matriks Leslie sehingga dihasilkan model Leslie.

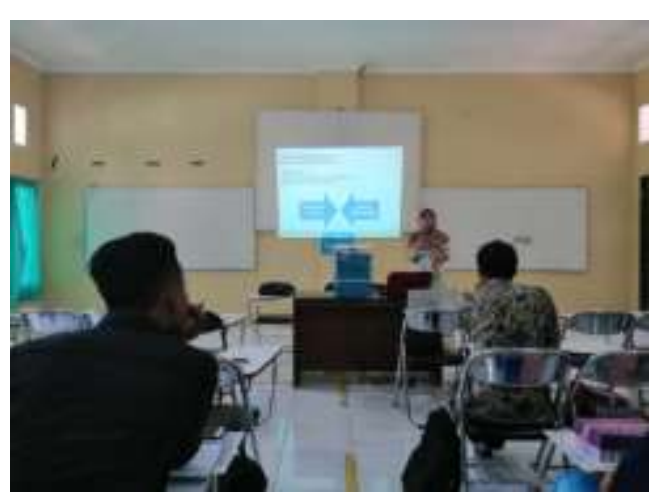

Gambar 3. Pemaparan materi tentang perkembangan Matriks Leslie

Materi terakhir adalah
tentang abstraksi bilangan prima.

Pada tahap ini dipaparkan bagaimana perkembangan konsep bilangan prima dari konsep yang biasa dikenal sampai ke abstraksinya yakni konsep keprimaan pada suatu struktur aljabar yakni ideal prima dan hampir prima sampai ke teori keprimaan yang lebih lanjut yaitu submodul prima, prima lemah dan hampir prima. Diberikan pula beberapa aplikasinya khususnya pada dunia kriptografi.

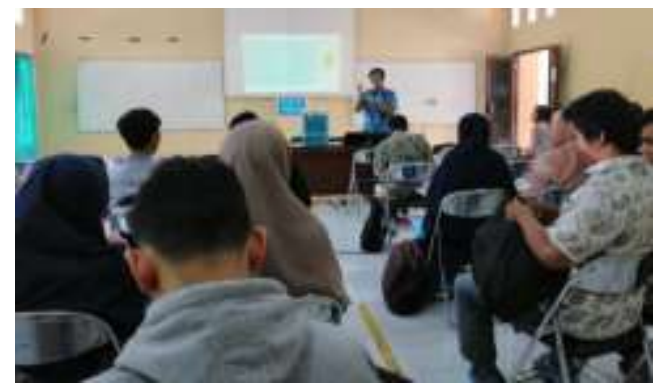

Gambar 4. Pemaparan materi tentang atraksi bilangan prima

Rangkaian terakhir dari acara ini adalah penutupan acara workshop yang ditutup oleh ketua kelompok riset Aljabar Prodi Matematika FMIPA Unram dan memberikan kesempatan berupa tawaran kepada mahasiswa untuk menentukan topik-topik aljabar yang diminati untuk dapat dijadikan topik penelitian dalam tulisan ilmiah maupun skripsi.

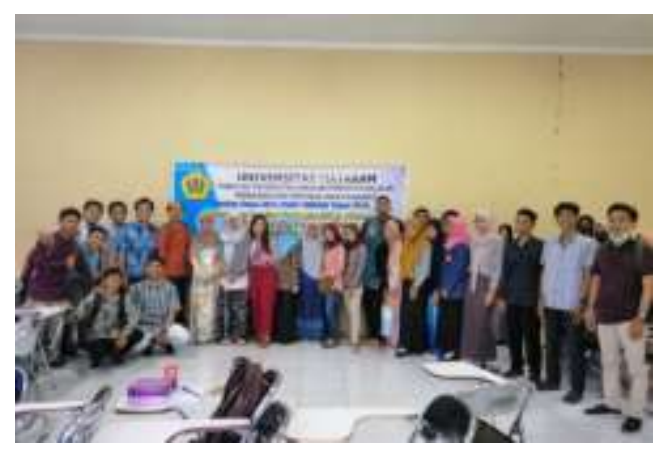

Gambar4. Dokumentasi bersama pemateri dengan peserta Adapun hasil dari kegiatan workshop isu-isu strategis dalam aljabar ini adalah: 
1. Pengetahuan mahasiswa peminat aljabar di Universitas Mataram meningkat dalam bidang aljabar dan aplikasinya.

2. Meningkatnya motivasi dan minat mahasiswa dalam bidang Aljabar dan aplikasinya. Hal ini terlihat dari rasa antusias yang tinggi dari para peserta dalam mengikuti kegiatan tersebut. Selain itu bahkan para mahasiswa peminat aljabar ini termotivasi untuk mengambil toik-topik aljabar untuk dijadikan sebagai topik skripsi.

Dalam pelaksanaan kegiatan Pengabdian Kepada Masyarakat ini, terdapat beberapa faktor yang mendukung kesuksesan kegiatan ini, antara lain sebagai berikut :

1. Dukungan Fakultas Matematika dan Ilmu Pengetahuan Alam yang telah menyediakan fasilitas ruangan demi terlaksananya kegiatan workshop ini.

2. Dukungan para dosen khususnya dosen Prodi Matematika Fakultas Matematika dan IImu Pengetahuan Alam dan dosen
Prodi Pendidikan Matematika yang telah mengerahkan dan mendampingi mahasiswanya untuk berpartisipasi dalam kegiatan ini.

3. Dukungan para mahasiswa peminat aljabar di Universitas Mataram yang sangat antusias dan bersemangat dalam mengikuti kegiatan workshop ini. Dalam setiap kegiatan tentunya terdapat beberapa hal yang menjadi faktor penghambat dalam pelaksanaan kegiatan tersebut. Begitu pula dalam pelaksanaan kegiatan Pengabdian Kepada Masyarakat ini, terdapat faktor penghambat dalam pelaksanaan kegiatan ini yaitu beberapa mahasiswa peminat aljabar di Universitas Mataram khususnya di Prodi Matematika Fakultas Matematika dan Ilmu Pengetahuan Alam tidak dapat menghadiri kegiatan workshop ini dikarenakan ada kegiatan perkuliahan dan acara seminar nasional yang sedang berlangsung pada waktu yang sama. 


\section{KESIMPULAN DAN SARAN \\ Kesimpulan}

Dari pelaksanaan kegiatan workshop isu-isu aljabar dalam rangka Pengabdian Kepada Masyarakat tersebut, dapat disimpulkan bahwa kegiatan tersebut sangat bermanfaat bagi para mahasiswa peminat aljabar di Universitas Mataram, yaitu dalam hal meningkatnya pengetahuan dan wawasan mahasiswa peminat aljabar di Universitas Mataram terhadap topik-topik aljabar yang sedang menjadi trend masa kini khususnya yang mengarah pada aplikasinya dalam dunia nyata Selain itu, mahasiswa juga lebih mudah menentukan rencana topik-topik penelitian baik untuk dijadikan bahan karya ilmiah maupun topik skripsi.

Saran

Adapun saran yang dapat diberikan adalah hendaknya kegiatan ini dapat dilakukan secara lebih rutin walaupun dalam cakupan yang lebih kecil sehingga dapat meningkatkan pengetahuan mahasiswa dalam bidang aljabar dan jumlah mahasiswa peminat aljabar juga semakin meningkat di Universitas Mataram, sehingga dapat menghasilkan banyak karya ilmiah maupun skripsi dalam bidang aljabar atau aplikasinya.

\section{UCAPAN TERIMAKASIH}

Ucapan terima kasih disampaikan kepada Universitas Mataram yang telah mendanai kegiatan Pengabdian Kepada Masyarakat ini melalui sumber dana DIPA PNBP dan Fakultas Matematika dan Ilmu Pengetahuan Alam Universitas Mataram yang telah menyediakan fasilitas ruangan demi terlaksananya kegiatan ini.

\section{DAFTAR PUSTAKA}

Anton, H., and Rorres, C., 2014. Elementary Linear Algebra 11th Edition. WileyPlus, United States of America.

Dimca, A., 2017. Hyperplane Arrangements. Springer, France.

Lady, Lee, 2017. The Origin of Abstract Agebra.

http://www.math.hawaii.edu / lee/algebra/history.html. Diakses: 5 April 2018. Wikipedia, $2018 . \quad$ Aljabar. https://id.org/wiki/Aljabar. Diakses: 5 April 2018.

